International Journal of Current Micro6iology and Applied Sciences

ISSN: 2319-7706 Volume 9 Number 9 (2020)

Journal homepage: http://www.ijcmas.com

Original Research Article

https://doi.org/10.20546/ijcmas.2020.909.157

\title{
Insect Pollinators of Pumpkin (Cucurbita pepo L.) and their Foraging Behaviour
}

\author{
S. R. Umesh*, Anil Kumar Vyas and M. K. Mahla \\ Department of Entomology, Rajasthan College of Agriculture, Maharana Pratap University of \\ Agriculture and Technology, Udaipur-313 001, Rajasthan, India \\ *Corresponding author
}

\section{A B S T R A C T}

\begin{tabular}{l} 
K e y w o r d s \\
Insect pollinators, \\
Pumpkin, \\
Botanicals, Crop \\
pest \\
\hline Article Info \\
$\begin{array}{l}\text { Accepted: } \\
\text { 12 August } 2020 \\
\text { Available Online: } \\
\text { 10 September } 2020\end{array}$ \\
\hline
\end{tabular}

Introduction

Pumpkin, Cucurbita pepo L. belongs to the family Cucurbitaceae and is grown extensively during kharif and summer season throughout India. It was brought in to India around $9^{\text {th }}$ century from South America (Pearce and Pearce, 2010). They are limited in temperate regions because of their sensitivity to frost (Tsuchiya and Gupta, 1991). Pumpkin is not only used as a vegetable for cooking (Okoli, 1984), but also has good medicinal properties. In India the area under pumpkin cultivation is 78,000 ha with a total production is 17.14lakh metric tonnes
(Annon. 2018). India is the second largest country producing pumpkin in the world after China.

The appearance of pollinators in cross pollination of important agro-horticultural crops is well appreciated. Among the 95 per cent cross pollinated flowers, 85 per cent depend on insect pollination (Carruth,1950). The important pollinators are honey bees, bumble bees (Bombus), solitary bees (Xylocopa, Andrena, Halictus) stingless bees (Trigona, Melipona) and many kinds of flies (Syrphus, Bombilius), black ants, thrips, beetles and moths. The insects belonging to 
the super-family Apoidea (Hymenoptera) are the most important pollinators of cucurbits.

Detailed work on foraging behaviour of pollinators of pumpkin is lacking. Though the flowers are visited by several species of bees, recognition of most ideal pollinator, its activity coinciding with time of stigma receptivity and pollen viability, need investigation. In general, botanicals act quickly, degrade rapidly and have, with a few exceptions, low mammalian toxicity. They are environmental friendly and safe to the insect pollinators as compared to the synthetic insecticides. Therefore, the present investigation on, Insect Pollinators of Pumpkin (Cucurbita pepo L.) and their Foraging Behaviour was carried out.

\section{Materials and Methods}

The present investigation was conducted at the Instructional Horticulture Farm and the Department of Entomology, Rajasthan college of Agriculture, MPUAT, Udaipur during kharif 2019. Udaipur is located at $24^{\circ} 35^{\prime} \mathrm{N}$ latitude and $73^{\circ} 42^{\prime} \mathrm{E}$ longitude at an elevation of 582.17 MSL (Mean Sea Level) in the state of Rajasthan. The region comes under agroclimatic zone IVa (Sub-Humid Southern Plain and Aravalli Hills of Rajasthan). Pumpkin variety (MAHY 1) was raised in a field with a plot size of $4 \times 2 \mathrm{~m}$ with a spacing of $90 \times 90$ $\mathrm{cm}$.Timely weeding and hoeing operations were implemented as per the package of practices (manual weeding was performed at 20 and 30 days after sowing). Recommended doses of $\mathrm{N}$ : P: K (70:25:25 kg/ha) were applied to the crop. The crop was rainfed, but during periods of dry spell irrigation was given.

The diversity of insect pollinators of pumpkin was observed during flowering at $10 \mathrm{am}, 12$ noon, $4 \mathrm{pm}$ for five minutes per square meter area during peak flowering period. There were 5 such spots for observation. The data were later averaged according to time wise and insect group wise to infer the pollinator fauna as well as the dominance of a particular group. The foraging behaviour of major insect pollinators of pumpkin was observed at two hours interval from 0600 to $1600 \mathrm{hr}$ on number of bees visiting each square meter area for five minutes at 5 days intervals from five percent flowering. There was five such spots for each observation. Observations was continued from 5 percent flowering till the spraying of botanicals.

The treatments comprised of:Azadirachta seed kernel extract-5\%, Azadirachta leaf extract-10\%, Azadirachta oil-1\%, Dusparni$10 \%$, Teekha sat-3\%. Each treatment was replicated 4 times. The number of major pollinators during their peak foraging period was counted one day before treatment and 1, 3 and 5 days after the treatments. The decrease or increase in the insect pollinators population was evaluated 1, 3 and 5 days after the application of botanicals. Later, the reduction in insect population was estimated one day after the spray of the botanicals by using the methodology given by Henderson and Tilton (1955); whereas 3 and 5 days after the spray of botanicals the average per centage increase or decrease in insect pollinator abundance was computed over control.

\section{Results and Discussion}

The flower of pumpkin attracts different insects belonging to the order Hymenoptera, Lepidoptera and Diptera. During estimation, total of 7 species were found foraging on pumpkin flowers. The most dominant species was honey bees (81.68\%). Wasps, butterflies and syrphids are the pollinators other than honey bees. It contributes $17.97 \%$ to pollinators fauna. Among honey bees, the most dominant and common species was Apis 
dorsata (67.40\%) followed by A. florea $(14.28 \%)$. The present results are in accordance with the results of Nicodema et al., (2009), Ali et al., (2014) who reported that pollination in pumpkin was mainly depends on bees.
Apis dorsata activity was observed from 0600-1300 hrs with peak activity at 09001000 hrs. Bee activity was suddenly decreased after $1300 \mathrm{hr}$ could be due to the closing of pumpkin flowers after $1100 \mathrm{hr}$ of the day. The foraging behaviour of A. dorsata was seen throughout the flowering period.

Table.1 Foraging behaviour of Apis dorsata on pumpkin

\begin{tabular}{|c|c|c|c|c|c|c|}
\hline \multirow{2}{*}{$\begin{array}{l}\text { Hours of } \\
\text { the day }\end{array}$} & \multicolumn{4}{|c|}{ Number of bees $/ \mathrm{m}^{2} / 5 \mathrm{~min}$} & \multirow[b]{2}{*}{ Total } & \multirow[b]{2}{*}{ Mean } \\
\hline & 1DAF & 5DAF & 10DAF & 15DAF & & \\
\hline 0600-0700 & 1.6 & 3.4 & 3.8 & 3.2 & 12 & 3 \\
\hline 0700-0800 & 5.2 & 6 & 6.6 & 7.8 & 25.6 & 6.4 \\
\hline 0800-0900 & 5.4 & 9.6 & 5.6 & 9.2 & 29.8 & 7.45 \\
\hline 0900-1000 & 11 & 10.2 & 13.4 & 12.4 & 47 & 11.75 \\
\hline $1000-1100$ & 9.2 & 8.2 & 9.6 & 8.4 & 35.4 & 8.85 \\
\hline $1100-1200$ & 6.4 & 9 & 6.8 & 8.2 & 30.4 & 7.6 \\
\hline $1200-1300$ & 4.6 & 3.8 & 2.8 & 3.4 & 14.6 & 3.65 \\
\hline $1300-1400$ & 0 & 0 & 0 & 0 & 0 & 0 \\
\hline $1400-1500$ & 0 & 0 & 0 & 0 & 0 & 0 \\
\hline $1500-1600$ & 0 & 0 & 0 & 0 & 0 & 0 \\
\hline Total & 43.4 & 50.2 & 48.6 & 52.6 & & \\
\hline Mean & 4.34 & 5.02 & 4.86 & 5.26 & & \\
\hline
\end{tabular}

DAF-Days after five per cent flowering

Table.2 Foraging behaviour of Apis florea on pumpkin

\begin{tabular}{|c|c|c|c|c|c|c|}
\hline \multirow{2}{*}{$\begin{array}{l}\text { Hours of } \\
\text { the day }\end{array}$} & \multicolumn{4}{|c|}{ Number of Bees $/ \mathrm{m}^{2} / 5 \mathrm{~min}$} & \multirow[t]{2}{*}{ Total } & \multirow[t]{2}{*}{ Mean } \\
\hline & 1DAF & 5DAF & 10DAF & 15DAF & & \\
\hline 0600-0700 & 0 & 0 & 0 & 0 & 0 & 0 \\
\hline 0700-0800 & 0.8 & 0.6 & 1.4 & 1.6 & 4.4 & 1.1 \\
\hline 0800-0900 & 1.6 & 1.8 & 2 & 2.4 & 7.8 & 1.95 \\
\hline 0900-1000 & 1.2 & 0.8 & 1.4 & 1 & 4.4 & 1.1 \\
\hline $1000-1100$ & 0.8 & 0.6 & 1.4 & 0.6 & $3.4 \mathrm{~s}$ & 0.85 \\
\hline $1100-1200$ & 0.6 & 0.2 & 0.6 & 0.6 & 2 & 0.5 \\
\hline $1200-1300$ & 0.6 & 0.2 & 0.4 & 0.4 & 1.6 & 0.4 \\
\hline $1300-1400$ & 0.4 & 0 & 0.2 & 0 & 0.6 & 0.15 \\
\hline $1400-1500$ & 0 & 0 & 0 & 0 & 0 & 0 \\
\hline $1500-1600$ & 0 & 0 & 0 & 0 & 0 & 0 \\
\hline Total & 6 & 4.2 & 7.4 & 6.6 & & \\
\hline Mean & 0.6 & 0.42 & 0.74 & 0.66 & & \\
\hline
\end{tabular}

DAF-Days after five per cent flowering 
Table.3 Effect of botanicals on the mean insect pollinator intensity over control

\begin{tabular}{|c|c|c|c|}
\hline Treatments & \multicolumn{3}{|c|}{ Pollinator intensity (\%) } \\
\hline $\begin{array}{c}\text { Azadirachtin seed } \\
\text { kernel extract (5\%) }\end{array}$ & $\begin{array}{c}\text { I day } \\
(-) 7.95\end{array}$ & III day & V day \\
\hline $\begin{array}{c}\text { Azadirachtin leaf } \\
\text { extract (10\%) }\end{array}$ & $(-) 14.77$ & $(+) 9.09$ & $(+) 13.41$ \\
\hline Azadirachtin oil (1\%) & $(20.58)$ & $(+) 2.43$ & $(+) 6.09$ \\
\hline Dashparni (10\%) & $(-) 20.45$ & $(-) 8.75$ & $(-) 17.07$ \\
\hline Teekha sat (3\%) & $(-) 17.04$ & $(-) 6.25$ & $(-) 10.97$ \\
\hline S. Em. \pm & $(20.94)$ & $(-) 2.5$ & $(+) 2.43$ \\
\hline C. D. & $(18.57)$ & & \\
\hline
\end{tabular}

* Figures in parenthesis are arc sine values, + indicates per cent increase in pollinator intensity and - indicates per cent decrease in pollinator intensity

The present results are in accordance with the results of Thakur and Rana (2008) who reported that the foraging activity of insect pollinators was peaked between 0900 and $1000 \mathrm{hr}$ of the day. Kumar (2010) observed that the foraging activity of $A$. dorsata was peaked between 0800-1000 hrs of the day (Table 1).

A. florea activity was observed from 0600$1400 \mathrm{hrs}$ with peak activity at 0800-0900 hrs. Bee activity was suddenly decreased after $1400 \mathrm{hr}$ could be due to the closing of pumpkin flowers after $1100 \mathrm{hr}$ of the day. The foraging behaviour of $A$. florea was seen throughout the flowering period. The present results more or less accordance with the results of Subhakar et al., (2011) who reported that foraging activity of A. florea was maximum at 0900-1000 hrs of the day. Kumar et al., (2012) reported that the foraging activity of Hymenopteran insects was found to be high from $0800 \mathrm{~h}$ to $1000 \mathrm{hrs}$ of the day (Table 2).

When a comparison was made between treatments and control with regard to insect pollinator population, one day after the spray of botanicals on pumpkin crop against red pumpkin beetle (Raphidopalpa foveicollis), the side-effect of the botanicals was showed a decrease in insect pollinator intensity ranging from 7.95 to $20.45 \%$ (Table 3). Effect of botanicals on the major insect pest of pumpkin observed that neem seed kernel extract $(5 \%)$ was more effective against red pumpkin beetle followed by neem leaf extract (10\%). The minimum number of red pumpkin beetle $/ \mathrm{m}^{2}$ was found in the plot treated with neem seed kernel extract (5\%) (1.31) and neem leaf extract (10\%) (1.57). In botanical treated plots, the maximum number of beetles $/ \mathrm{m}^{2}$ were recorded in the plots treated with Dusparni (10\%) (1.91), Teekha sat (3\%) (1.86) and neem oil (1\%) (1.78). The present results are in accordance with the results of Singh et al., (2010) reported that the maximum reduction of insect pollinators $(25.06 \%)$ was recorded from plots treated with neem seed oil (1\%) and 3 days after the pollinator percentage increased in plots treated with NSKE (5\%) and neem leaf extract (10\%). Khan et al., (2015) reported that ethanolic-extracts of Azadirachta indica 
5\% causes $76.7 \%$ repellency against Aulocophora foveicollis Lucas adults.

In conclusion the based on the outcome of the present investigations, it could be concluded that the pumpkin attracts large number of insects as pollinators in which the honey bees were the major group. Among honey bees, $A$. dorsata play a major role. Among botanicals treated, application of neem seed kernel extract $5 \%$ for the management of red pumpkin beetle is an appropriate control measure with less health risk and also safe for social insects.

\section{References}

Ali, M., Saeed, S., Sajjad, A., Sajjad, S. and Bashir, M. A. 2014. Exploring the best native pollinators for pumpkin (Cucurbita pepo) production in Punjab, Pakistan. Pakistan Journal of Zoology 46:531-539.

Anonymous. 2018. Area, production and productivity of pumpkin in India. (201718). Horticultural statistics at glance, Directorate of Economics and Ministry of Agriculture and Farmer Welfare, Government of India.

Carruth, L.A. 1950. Fundamental principles of pollination. Report Iowa State Apiarist, pp. 65-67.

Khan, R. R., Ahmed, S., Arshad, M. and Samiullah. 2015. Laboratory assessment of repellency and insecticide efficacy of some plant extracts against adults of Red pumpkin beetle (Aulacophora foveicollis Lucas). Pakistan Journal of Life and Social Sciences 13: 49-57.

Kumar, B. P. 2010. Studies on insect pollinators on bitter gourd (Momordica charantia L.). M. Sc Thesis. Chaudhary Charan Singh Haryana Agricultural university, Hisar, India.

Kumar, P., Baskaran, S., Sundaravadivelan, C., Anburaj, J. and Kuberan, T. 2012. Insect visitors of pumpkin, Cucurbita maxima Duch., in relation to temperature and relative humidity. Journal of Agricultural Technology 8: 501-513.

Nicodemo, D., Counto, R. H. N., Malheiros, E. B. and Jong, D. 2009. Honey bee as an effective pollinating agent of pumpkin. Scientia Agicola (Piracicaba, Braz.) 66: 476-480.

Okoli, B. E. 1984. Wild and cultivated cucurbits in Nigeria. Economic botany38: 350-357.

Pearce, C. E. N. and Pearce, F. N. 2010. Oceanic migration; patts, sequence, timing and range of prehistoric migration in the pacific and Indian oceans. Springer, New York.

Singh, H., Swaminathan, R. and Hussain, T. 2010. Influence of certain plant products on the insect pollinators of coriander. Journal of Biopesticides3: 208-211.

Subhakar, G., Sreedevi, K., Manjula, K. and Reddy, N. P. E. 2011. Pollinator diversity and abundance in bitter gourd, Momordia charantia Linn. Pest Management in Horticultural Ecosystems 17: 23-27.

Thakur, M. and Rana, R. S. 2008. Studies on the role of insect pollination on cucumber yield. Pest Technology2: 130-133.

Tsuchiya, T. and Gupta, P. K. 1991. Chromosome engineering in plants: genetics, breeding and evolution, part $\mathrm{B}$. Fort Collins, Colorado, USA. 185195.

\section{How to cite this article:}

Umesh, S. R., Anil Kumar Vyas and Mahla, M. K. 2020. Insect Pollinators of Pumpkin (Cucurbita pepo L.) and their Foraging Behaviour. Int.J.Curr.Microbiol.App.Sci. 9(09): 12861290. doi: https://doi.org/10.20546/ijcmas.2020.909.157 